\title{
Changing trends of rainfall and sediment fluxes in the Kinta River catchment, Malaysia
}

\author{
WAN RUSLAN ISMAIL ${ }^{1} \&$ MOHMADISA HASHIM ${ }^{2}$ \\ 1 HydroGeomorphology Research Group, Geography Section, School of Humanities, Universiti Sains Malaysia, 11800 \\ Minden, Pulau Pinang, Malaysia \\ wruslan@usm.my \\ 2 Department of Geography and Environment, Faculty of Human Sciences, Universiti Pendidikan Sultan Idris, 35900 \\ Tanjong Malim, Perak, Malaysia
}

\begin{abstract}
The Kinta River, draining an area of $2566 \mathrm{~km}^{2}$, originates in the Korbu Mountain in Perak, Malaysia, and flows through heterogeneous, mixed land uses ranging from extensive forests to mining, rubber and oil palm plantations, and urban development. A land use change analysis of the Kinta River catchment was carried out together with assessment of the long-term trend in rainfall and sediment fluxes. The Mann-Kendall test was used to examine and assess the long-term trends in rainfall and its relationship with the sediment discharge trend. The land use analysis shows that forests, water bodies and mining land declined whilst built and agricultural land use increased significantly. This has influenced the sediment flux of the catchment. However, most of the rainfall stations and river gauging stations are experiencing an increasing trends, except at Kinta river at Tg. Rambutan. Sediment flux shows a net erosion for the period from 1961 to 1969 . The total annual sediment discharge in the Kinta River catchment was low with an average rate of $1,757 \mathrm{t} / \mathrm{km}^{2} /$ year. From 1970 to 1985 , the annual sediment yield rose to an average rate of $4062 \mathrm{t} / \mathrm{km}^{2} /$ year. Afterwards, from 1986 to 1993, the total annual sediment discharge decreased to an average rate of $1,306 \mathrm{t} / \mathrm{km}^{2} /$ year and increased back during the period 1994 to 2000 to $2109 \mathrm{t} / \mathrm{km}^{2} /$ year. From 2001 to 2006 the average sediment flux rate declined to $865 \mathrm{t} / \mathrm{km}^{2} /$ year. The decline was almost $80 \%$ from the 1970s. High sediment flux in the early 1970s is partly associated with reduced tin mining activities in the area. This decreasing trend in sediment delivery leaving the Kinta River catchment is expected to continue dropping in the future.
\end{abstract}

Key words rainfall; sediment fluxes; water discharge; land use change; Kinta River, Malaysia

\section{INTRODUCTION}

Sediment discharge can be defined as the portion of total suspended solids of sand, silt and mud that flow in the drainage basin and eventually out to the sea (Owens, 2008). Human activities are believed to be the primary driving force to the changing trends of streamflow and sediment discharge in many catchments (Zhang et al., 2008; Runstomji et al., 2008; Gao et al., 2011). Evidence from longer-term sediment load records indicates that river sediment fluxes are sensitive to many influences, including reservoir construction (Vörösmarty et al., 2003), land clearance and land-use change (Syvitski, 2003), other forms of land disturbance including mining activity, soil and water conservation measures and sediment control programmes, and climate change (Walling $\&$ Fang, 2003). Catchment activities and land-use changes can affect the trend in river discharge and sediment transport. Many studies have also shown that a changing trend in rainfall will affect the sediment and discharge trend in a catchment. Some of these influences cause sediment loads to increase, whilst others, namely, soil and water conservation and sediment control programmes, and reservoir construction can reduce sediment fluxes (Syvitski, 2003; Walling \& Fang, 2003). In many cases, it is difficult to differentiate the influence of climate change from that of other changes in a catchment. Although there is clear evidence that sediment loads of some rivers are changing, others show little evidence of any significant temporal trend (Walling \& Fang, 2003). This study investigates the long-term trend in sediment fluxes of the Kinta River and focuses on the annual rainfall trend, river discharge and sediment yields for the period 1961-2006.

\section{STUDY AREA}

This study focuses on the Kinta River catchment, the main tributary catchment of the Perak River system. The Kinta River flows from the Korbu and Ulu Kinta highland. The catchment drainage area is $2566 \mathrm{~km}^{2}$ and is elongated in shape. The elevation of the upper catchment is over $2000 \mathrm{~m}$ a.s.l. The eastern parts of the hilly area are covered by forests, medium slopes are covered by 
different agricultural crops and the flat area is covered by barren land and urban area. The upstream area consists of very steep slopes covered by primary jungle (Said et al., 2002).

The Kinta River is a seventh-order river based on Strahler's stream order classification. This high order indicates that the Kinta River consists of many tributary streams joining into the main stream (Fig. 1). The tribuaries include the Kampar, Pari, Raia, Chenderiang and Tumboh rivers

The Kinta River catchment has undergone a significant urbanisation compared to other subcatchments within the Perak River basin. Over the past several decades, forested areas and open water bodies have declined in the catchment whilst urban area and agricultural cropland have increased significantly. Agricultural land use was the second largest land use in the Kinta River basin after forest. Although the overall trend of agricultural land use from 1974 to 2004 shows an increasing pattern, during the earlier part of the period the agriculture land use decreased from $659 \mathrm{~km}^{2}$ in 1974 to $656 \mathrm{~km}^{2}$ in 1984 and further declined to $611 \mathrm{~km}^{2}$ in 1990 . Agricultural land use then increased in 1997 and 2004 to 691 and $721 \mathrm{~km}^{2}$, respectively. Based on the 2004 land-use map, the present land uses comprise forest $\left(1184 \mathrm{~km}^{2} ; 46 \%\right)$, agriculture $\left(721 \mathrm{~km}^{2} ; 28 \%\right)$, tin mining land, and quarry $\left(333 \mathrm{~km}^{2} ; 13 \%\right)$. Table 1 summarizes the changing land use history from 1970s to present. Much of the change in the land use and hydrology occured due to mining and reclamation and conversion of mined wasteland to agriculture, human settlements and others.

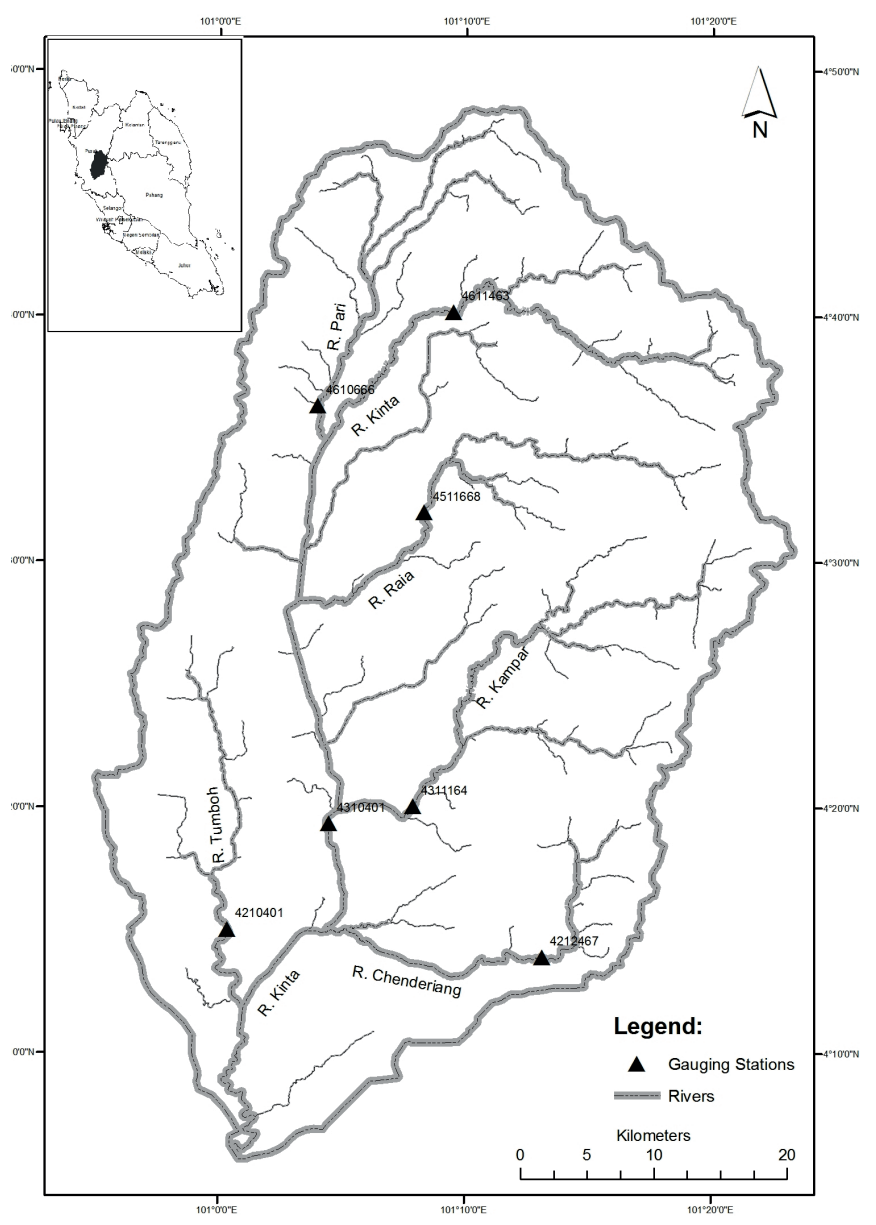

Fig. 1 Kinta River and its main tributaries showing the gauging stations.

\section{METHODS}

Hydrological data series (1960s-2006) of daily precipitation, river discharge and sediment discharge in the Kinta catchment were collected from the Drainage and Irrigation Department of Malaysia (DID). A total of seven rainfall stations and river gauging stations were used (Fig. 1). All data were first qualitatively checked for missing values and linear regression analysis was 
Table 1 Changes of land-use area in Kinta River catchment $\left(\mathrm{km}^{2}\right)$.

\begin{tabular}{|c|c|c|c|c|c|c|c|c|c|c|c|}
\hline \multirow[t]{2}{*}{ Land use } & \multicolumn{2}{|l|}{1974} & \multicolumn{2}{|l|}{1984} & \multicolumn{2}{|l|}{1990} & \multicolumn{2}{|l|}{1997} & \multicolumn{2}{|l|}{2004} & \multirow{2}{*}{$\begin{array}{l}\text { \% change } \\
1974-2004\end{array}$} \\
\hline & $\mathrm{km}^{2}$ & $\%$ & $\mathrm{~km}^{2}$ & $\%$ & $\mathrm{~km}^{2}$ & $\%$ & $\mathrm{~km}^{2}$ & $\%$ & $\mathrm{~km}^{2}$ & $\%$ & \\
\hline Forest & 1350 & 53 & 1326 & 52 & 1293 & 50 & 1204 & 47 & 1184 & 46 & -12.3 \\
\hline Agriculture & 659 & 26 & 656 & 26 & 611 & 24 & 691 & 27 & 721 & 28 & 9.4 \\
\hline Water bodies & 445 & 17 & 484 & 19 & 452 & 18 & 463 & 18 & 417 & 16 & -6.3 \\
\hline Built-up & 111 & 5 & 100 & 4 & 210 & 8 & 207 & 8 & 244 & 10 & 119.8 \\
\hline Total & 2566 & 100 & 2566 & 100 & 2566 & 100 & 2566 & 100 & 2566 & 100 & \\
\hline
\end{tabular}

performed in the interest of the missing rainfall and discharge data. Similarly, for missing sediment discharge data, the discharge value was calculated using the rating relationship between discharge stations. Then, sediment yield analysis was performed to estimate the rate of catchment areas experiencing land-use changes, and to measure the amount of sediment carried by the river.

The land-use change information was obtained from the Department of Agriculture Peninsular Malaysia, and was analysed using a geographic information system (GIS). Four major types of land use were classified to identify any long-term changes of forest land use, water bodies, agriculture, and built-up areas (Table 1). The Mann-Kendall test was used to determine significance in the long-term trend of rainfall, discharge and sediment discharge in the Kinta catchment. Linear regression was used to identify whether the trends were increasing, decreasing or steady-state. The Mann-Kendall test is often used to further verify the trend's change in environmental time series data (Burn \& Elnur, 2002; Yue et al., 2003), and to confirm whether the trend is significant or not (Bae et al., 2008; Basistha et al., 2009).

\section{RESULTS AND DISCUSSION}

The observed changes in sediment yield of the tributaries of the Kinta River (Fig. 2) does not reflect the impacts of climate (rainfall) variability except at Ulu Kinta which directly affects the sediment discharge of the upper Kinta River at Tg. Rambutan (Kinta TR) (see also Table 2). This is because sediment discharge from the upper Kinta was small because the land use is mostly forest. Tropical rain forests were able to prevent $21-31 \%$ of rainfall from falling directly onto the ground and could reduce surface erosion rates and thus sediment production (Manokaran, 1979).

Other tributary, such as the Pari River, show a positive correlation between rainfall and sediment yield. This could be related to both, the changing rainfall and land use/anthropogenic activities in the catchment. Pari River flows through Ipoh City where much human intervention is taking place and also land-use changes especially related to land clearing for urbanisation. Many areas on the Ipoh City outskirts have been developed to meet population housing demands. Large areas of forest and agricultural plantation were turned into townships, which contribute further to the ever increasing sediment discharge in this basin.

Other rivers showed a negative correlation between rainfall and sediment yield, e.g. the Kampar, Raia and Chenderiang rivers, as they experience a declining trend in sediment yield with increasing rainfall trends. Similarly, the Kinta at Tg Tualang (Kinta TT) has a declining sediment trend with increasing climate factor. The sediment yield is higher at Kinta TT because it received all the sediment from the upper tributaries. Sediment of the Tumboh River changes little, despite the slightly increasing rainfall at the Nalla estate.

The contribution of anthropogenic activities in the catchments is discernible in the Raia and Chenderiang rivers. A lot of sediment flux came from Chenderiang between 1970-1985 (sometimes $>2000 \mathrm{t} / \mathrm{km}^{2} /$ year; Fig. 2). The declining sediment yield post 1985 could be partly related to decline in mining activities. The Malaysian Mines Department (1996) reported that the peak tin production was in $1972(72620 \mathrm{t}$ ) but declined to $37874 \mathrm{t}$ in 1983. The total acreage of mining areas in Perak declined to $53.88 \mathrm{~km}^{2}$ in 1996. Malaysia's contribution to global tin production, also declined progressively from $>40 \%$ in the early 1960 s to just over $20 \%$ in 1991 (Balamurugan, 1991). Estimated tin output was $7339 \mathrm{t}$ in 1999; $6307 \mathrm{t}$ in 2000, and declined to $3539 \mathrm{t}$ in $2003 \mathrm{(Wu}$, 2003). Nowadays, what is left of the mining land are numerous abandoned mining pools. 

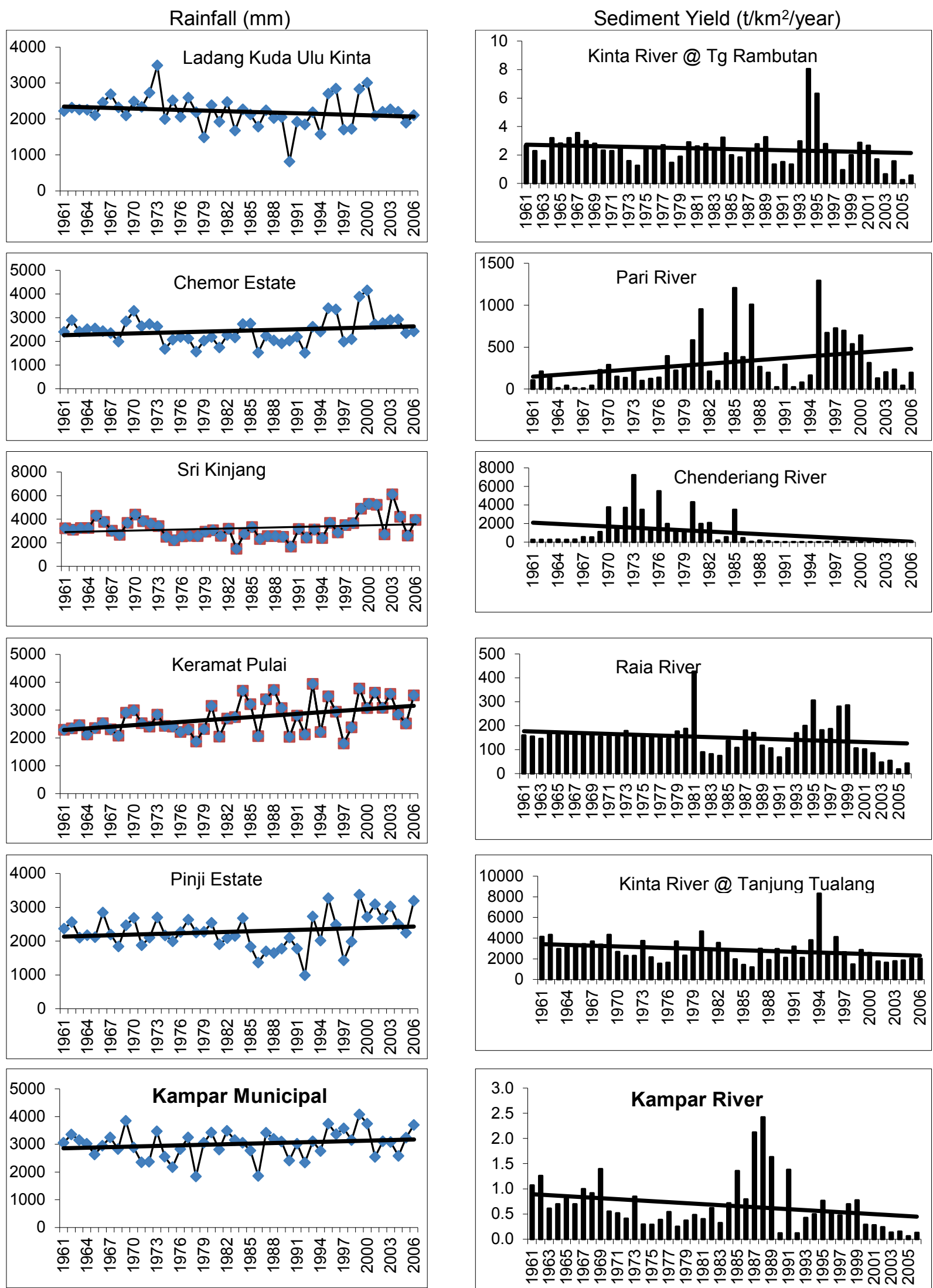

Fig. 2 Long-term trends of rainfall and sediment yield of major tributaries of the Kinta River catchment. Continued on next page. 

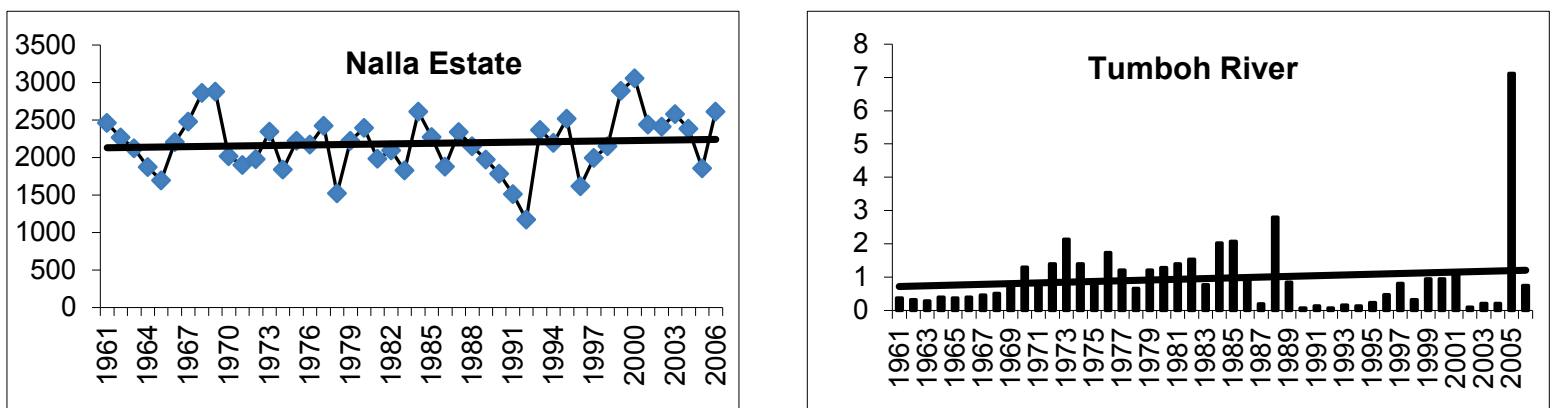

Fig. 2 Continued.

Table 2 Mann-Kendall test analysis for rainfall trend in the Kinta River catchment and sub-catchments, 1961-2006.

\begin{tabular}{lllllll}
\hline Sub-catchment & Rainfall stn & $\begin{array}{l}\text { Data } \\
\text { points } \\
(\mathrm{n})\end{array}$ & $\begin{array}{l}\text { Mann- } \\
\text { Kendall } \\
\text { statistic (S) }\end{array}$ & $\begin{array}{l}\text { Normal } \\
\text { statistical test } \\
(\mathrm{Z})\end{array}$ & $\begin{array}{l}\text { Probability } \\
(\mathrm{P})\end{array}$ & $\begin{array}{l}\text { Trend (at 99\% } \\
\text { confidence } \\
\text { level) }\end{array}$ \\
\hline Chenderiang & Sri Kinjang & 46 & 46 & 0.426 & 0.6700 & Increase \\
Kampar & Kampar town & 46 & 123 & 1.155 & 0.2480 & Increase \\
Raia & Keramat Pulai & 46 & 285 & 2.689 & 0.0072 & Increase \\
Kinta TR & Ulu Kinta & 46 & -163 & -1.534 & 0.1250 & Decrease \\
Pari & Chemor Est & 46 & 77 & 0.720 & 0.4718 & Increase \\
Tumboh & Nalla Est & 46 & 72 & 0.672 & 0.5014 & Increase \\
Kinta TT & Pinji Est & 46 & 62 & 0.578 & 0.5635 & Increase \\
\hline
\end{tabular}

Table 3 Mann-Kendall test analysis for annual discharge trend for Kinta River catchment and subcatchments, 1961-2006.

\begin{tabular}{lllcll}
\hline Sub-Catchment & $\begin{array}{l}\text { Data } \\
\text { Points } \\
(\mathrm{n})\end{array}$ & $\begin{array}{l}\text { Mann- } \\
\text { Kendall } \\
\text { statistic }(\mathrm{S})\end{array}$ & $\begin{array}{l}\text { Normal } \\
\text { statistical test } \\
(\mathrm{Z})\end{array}$ & $\begin{array}{l}\text { Probability } \\
(\mathrm{P})\end{array}$ & $\begin{array}{l}\text { Trend (at 99\% } \\
\text { confidence } \\
\text { level) }\end{array}$ \\
\hline Chenderiang & 46 & 166 & 1.563 & 0.118 & Increase \\
Kampar & 46 & 204 & 1.922 & 0.055 & Increase \\
Raia & 46 & 115 & 1.080 & 0.280 & Increase \\
Kinta TR & 46 & -229 & -2.159 & 0.031 & Decrease \\
Pari & 46 & 51 & 0.474 & 0.636 & Increase \\
Tumboh & 46 & -8 & -0.066 & 0.947 & Decrease \\
Kinta TT & 46 & 170 & 1.600 & 0.109 & Increase \\
Kinta River catchment (KRC) & 46 & 232 & 2.187 & 0.029 & Increase
\end{tabular}

Notes: Kinta TR is for Kinta River at Tg. Rambutan; Kinta TT for Kinta River at Tg. Tualang;

Sediment yield is the product of water discharge and sediment concentration. Therefore, the declining trends of discharge at Kinta TR and Tumboh River (Table 3) will affect and explain the declining sediment yield trend of the two rivers respectively (Fig. 2).

Further calculation of the sediment discharged from the whole Kinta River revealed that the sediment discharge trend could be divided into five phases during this 46-year period. The first period was from 1961 to 1969 . The total annual sediment discharge in the Kinta River catchment was low with an average of $1757 \mathrm{t} / \mathrm{km}^{2} /$ year. Then in $1970-1985$, the total annual sediment discharge rose to an average of $4062 \mathrm{t} / \mathrm{km}^{2} /$ year. From 1986 to 1993 , the sediment discharge decreased to an average of $1306 \mathrm{t} / \mathrm{km}^{2} /$ year, and then increased during 1994-2000 to 2109 $\mathrm{t} / \mathrm{km}^{2} /$ year. Finally, from 2001 to 2006 the average was reduced to $865 \mathrm{t} / \mathrm{km}^{2} /$ year. The decline in sediment discharge was almost $79 \%$ from 1970 s and this trend is expected to decrease further into the future. 


\section{CONCLUSIONS}

Drainage catchments are dynamic and constantly changing due to the effects of natural factors and human activities. Rainfall is the major source of runoff in a drainage catchment and at the same time change of land use caused by human activities can increase the amount of sediment discharge due to excess soil erosion. This study found that rainfall did not really influence the sediment discharge but rather the interplay between rainfall and land-use activities affecting sediment production. Discharge trends in the Kinta catchment are increasing in the long run, but sediment yield is decreasing. The information about long-term trends of discharge, sediment yield and landuse changes in the Kinta River catchment is important for developing sustainable land management strategies and plans for future generations. The sediment discharge trend showed a declining sediment discharge from 1961 to 2006 with a reduction of nearly $80 \%$. In accordance with this decreasing trend, it is possible to foresee that the trend of sediment leaving the Kinta River catchment will continue to decline in the future.

\section{REFERENCES}

Bae, D.-H., Jung, I.W. \& Chang, H. (2008) Long-term trend of precipitation and runoff in Korean river basins. Hydrological Processes 22, 2644-2656.

Balamurugan, G. (1991) Tin mining and sediment supply in Peninsular Malaysia with special reference to the Kelang river basin. The Environmentalist 11(4), 281-291.

Basistha, A., Arya, D. S. \& Goel, N. K. (2009) Analysis of historical changes in rainfall in the Indian Himalaya. International Journal of Climatology 29, 555-572.

Burn, D. H. \& Elnur, M. A. H. (2002) Detection of hydrologic trends and variability. Journal of Hydrology 255, $107-122$.

Gao, P., et al. (2011) Changes in streamflow and sediment discharge and the response to human activities in the middle reaches of the Yellow River. Hydrol. Earth Syst. Sci. 15, 1-10.

Malaysian Mines Department (1996) Annual Report 1996. Kuala Lumpur.

Manokaran, N. (1979) Steamflow, throughfall and rainfall interception in a lowland tropical rainforest in Peninsular Malaysia. Malay Forester 421, 174-201.

Owens, P. N. (2008) Sediment behaviour, functions and management in river basins. In: Owens, P.N. (ed.), Sustainability Management of Sediment Resources. Amsterdam: Elsevier, 1-29.

Rustomji, P., et al. (2008) River sediment load and concentration responses to changes in hydrology and catchment management in the Loess Plateau region of China. Water Resour. Res., 44, W00A04, doi:10.1029/3008WRR006656.

Said, A.M., et al. (2002) The application of remote sensing and GIS in monitoring land-use/land cover changes for a study area in Ipoh. Procs. Int. Conf. on Environmental Issues and Sustainable Development. Kuala Lumpur, Malaysia.

Syvitski, J. P. M. (2003) Supply and flux of sediment along hydrological pathways: Research for the $21^{\text {st }}$ century. Global and Planetary Change 39, 1-11.

Vörösmarty, C.J., et al. (2003) Anthropogenic sediment retention: Major global impact from registered river impoundments. Global and Planetary Change 39, 169-190.

Walling, D. E. \& Fang, D. (2003) Recent trends in the suspended sediment loads of the world's rivers. Global and Planetary Change 39, 111-126.

Wu, J.C. (2003) The mineral industry of Malaysia. Country report in USGS Minerals Yearbook 2003. 16.1-16.7. USGS Publication.

Yue, S., Pilon, P. \& Phinney, B. (2003) Canadian streamflow trend detection: Impacts of serial and cross-correlation. Hydrological Sciences Journal, 48 (1), 51-63.

Zhang, X. P., et al. (2008) Responses of streamflow to changes in climate and land use/cover change in Loess Plateau, China. Water Resour. Res., 44, W00A07, doi:10.1029/2007WR006711. 